\title{
Pachamama y desarrollo: paisajes conflictivos en el Desierto de Atacama
}

Alonso Barros

\section{RESUMEN}

Basado en la experiencia adquirida trabajando con las comunidades atacameñas, este trabajo analiza las disputas que con frecuencia las oponen con el Estado chileno y los efectos de sus políticas económicas. Esas disputas, principalmente expresadas en términos de posiciones contrapuestas respecto de quién debiera tener control sobre los recursos locales: agua, tierra, subsuelo, paisajes, revelan las divergencias conceptuales y epistemológicas que subyacen a dichos conflictos. Al describir y desconstruir el discurso desarrollista del Estado respecto del territorio en disputa, por un lado, y analizar los modos atacameños de habitar su territorio y poblar su paisaje, por el otro, se hace cada vez más evidente que la Pachamama y el discurso y prácticas del desarrollo chileno están basados en nociones diferentes respecto de la subjetividad, del espacio/tiempo, de la ecología y de cuáles son las relaciones significativas entre ellas. A modo de conclusión, el artículo muestra como estas diferentes perspectivas y epistemologías son proyectadas a nivel administrativo y legal, tanto localmente como a nivel nacional, así como algunas de las estrategias indígenas para contrarrestadas.

\section{ABSTRACT}

Drawing from experience gathered working with Atacameño communities in the Atacama desert, Chile, this paper analyses the clashes that often oppose them to the Chilean State and the effects of its economic policies. These clashes, mainly expressed in terms of exclusive land claims, reveal the different underlying meanings 'land' as for both the State and the Atacameños. By describing and deconstructing the development discourse the State deploys about the disputed territory, on one side, and analyzing atacameño modes of dwelling the land and populating the landscape, on the order, it becomes increasingly clear how the andean Pachamama (short for Cosmos, land, earth) and Development discourse are based on differing notions of subjectivity, space/time, ecology and meaningful relationships between them. By way of conclusion, the paper shows how these differing views and epistemologies are played out at the administrative and legal fields, both locally and at a national level.

\section{Orígenes y virtudes del paisaje en antropología}

¿Qué relevancia tiene el paisaje para la teoría y practica de la antropología del desarrollo? ¿Por qué 'paisaje' y el brote de libros como los editados por Bender (1993), Tilley (1994), Hirsch y O'Hanlon (1995), y Feld y Basso (1996), que intentan narrarnos las diferentes maneras en que los paisajes pueden ser percibidos, apropiados, contestados, formados, negociados? ¿Cuales son los potenciales analíticos de considerar las variadas relaciones en las cuales se involucran los seres humanos con sus paisajes?

El paisaje ha estado presente en la literatura antropológica casi desde los inicios mismos de la disciplina: "de dos maneras relacionadas: a) como convención demarcadora, una escena, una referencia a partir de la cual el antropólogo trae su materia de estudio a la vista, una convención que Malinowski usó para crear un efecto participativo. b) El sentido imputado al entorno físico y cultural por la población local"(Hirsch, 1995:1). Hace relativamente poco que el "paisaje" adquiere mayor relevancia como categoría analítica al permitir dar cuenta de conflictos y escenarios culturales más complejos.

Un breve análisis semántico de la reciente historia del "paisaje" en antropología, pondría, sin lugar a dudas, las reclamaciones territoriales de los aborígenes australianos a la raíz de este renovado interés: "muchos de los temas en la antropología del paisaje están prefigurados en la literatura Australiana" 
(Morphy 1993:206). Reveladoramente, es en un contexto de conflicto -mientras reclamaciones territoriales eran planteadas (y opuestas) bajo la legislación de la. Australian Northern Tertitory Land Rights- que fue intentado este novel esfuerzo para la comprensión de las relaciones hombre-entorno. En este marco, se hizo cada vez más urgente para los antropólogos -en muchos casos abogando en pro de las reclamaciones indígenas-, demostrar, de alguna manera, la real importancia y rol que tenían los "territorios tradicionales" en la supervivencia cultural y material de los grupos aborígenes.

La primera situación que obviamente parecía requerir de reconocimiento y protección legal era la de la utilización indígena de recursos. La pérdida progresiva de control sobre los recursos que los pueblos indígenas usaban (y no usaban) tradicionalmente -y las secuelas de progresiva "muerte cultural"- no era ya considerada producto de un alineamiento fortuito de circunstancias desfavorables, sino que una situación con claros antecedentes coloniales y desarrollos post-coloniales.

Los pueblos indígenas y los territorios que reclamaban (y reclaman aún), principalmente en Canadá, Australia y las Américas, estaban enfrentando crecientes presiones medioambientales y sociales. Las industrias ganaderas, forestales y mineras, entre otras actividades "degradadoras del medio ambiente", estaban (y están) directa o indirectamente amenazando los modos de vida indígenas. En un intento por poner fin a las crecientes pérdidas materiales y culturales, algunos pueblos indígenas comenzaron a reclamar derechos exclusivos sobre aguas y tierras. Estos, empero, reconocidos sólo en base al uso demostrado y efectivo, no bastaban para garantizar adecuadamente la supervivencia indígena.

Nuevos escenarios socio-políticos (reclamaciones indígenas, mayor conciencia medioambiental, nuevos movimientos sociales), promovieron el distanciamiento paulatino del uso de palabras restrictivas como "recursos", "propiedad", "derechos sobre tierras" y "uso de suelos", hacia uno de palabras más inclusivas. Términos con vocación a abarcarlo todo, como "medio ambiente" y "ecología" fueron crecientemente empleados, ya que parecían más aptos para describir la real dimensión de las reclamaciones indígenas.

Terence Turner describe como, hacia fines de los 80 y principios de los 90 , esta senda llevó a que las reclamaciones territoriales del "Cuarto Mundo" fueran fervientemente coadyuvadas por ONGs medioarnbientalistas: el mito romántico del "noble salvaje" en armonía con su entorno fue reinventado y transformado en aquel de los "Guardianes de la Selva", mito hecho a medida para el área Amazónica.

Estos "Guardianes", sin embargo, manifestaban tener otros intereses: "Yo no creo que puedan decir que los pueblos indigenas son conservacionistas, siguiendo la definición ecologista. No somos amantes de la naturaleza. En ningún momento han los grupos indigenas incluido los conceptos de "conservación" y "ecología" en su vocabulario tradicional" (de una entrevista con un indígena Kuna, en Redford y Stearman 1993:427).

Turner nos muestra, adicionalmente, cuán cierta es esta afirmación en el caso de muchas comunidades Kayapó: reclamaciones territoriales indígenas y preocupaciones ambientales no necesariamente forman un matrimonio feliz, como inicialmente se había creído.

Además, debido a las connotaciones impersonales de palabras tales como "medio ambiente" y "ecología", la terminología euroamericana se vio obligada a enfrentar sus propias carencias conceptuales. Hubo una creciente necesidad y búsqueda de términos que pudieran adecuadamente integrar y expresar, en un todo indivisible, nociones de uso de suelo, de valores rituales, simbólicos y sagrados asociados a la tierra, y -aunque tal vez expresado de modo "subalterno" (Spivak 1990:84)- crecientes preocupaciones medio ambientales.

La parafernalia conceptual euroamericana dispone de escasas palabras que se refieran simultáneamente a todas estas ideas, a primera vista tan disímiles. La palabra "holismo", por ejemplo, a menudo empleada para describir la epistemología e interrelaciones indígenas, es difícilmente traducible en términos de propiedad, recursos, derechos, medio ambiente, emoción, sitios sagrados. Cualquier esfuerzo en este sentido usualmente implica encasillar, limitar y eventualmente restringir "el punto de vista del nativo". La palabra "holismo", en sí, es descriptivamente vaga y obscura.

¿Cómo, entonces, dar cuenta adecuada de interrelaciones de tipo "holísticas" con un entorno sagrado, geofísico o social dado, sin caer en el terreno excesivamente vago, "esotérico", o extralegal de la religión y cosmovisión indígenas? Difícilmente se podría así construir sólidos argumentos en procedimientos judiciales de reclamación territorial. ¿Cómo obtener el reconocimiento legal de reclamaciones "holísticas"?

Esta deficiencia conceptual probablemente influyó en el cambio al uso de palabras que rindieran 
lo relacional y complejo de las relaciones hombremedio ambiente en forma más explícita y central: palabras como "morar" o lebenswelt y, particularmente, "paisaje".

El uso de recursos, los saberes locales, las estructuras clánicas, relaciones de parentesco y prácticas religiosas, proveyeron a los untropólogos estudiosos de los aborígenes australianos y sus "Huellas de Sueño" con argumentos para usar el "paisaje" como un término unificador, una palabra clave que describe un campo relacional total. El "paisaje" traducía más adecuadamente la amplitud del espectro de reclamaciones indígenas, y era suficientemente específico como para ser utilizado en los procedimientos legales (más que los "Sueños" aborígenes por sí solos).

Esta categoría analítica ofrecía, además, la posibilidad de entender conflictos -tanto pasados como presentes- que se producían en su ambiente: "Una cosmología basada en el paisaje es una de las maneras en que la identidad aborigen se ha mantenido en un contexto post-colonial, y también, una de las áreas de conflicto entre australianos negros y blancos. El paisaje provee un excelente marco analítico para representar el choque de valores y los intereses divergentes de aborigenes y colonizadores. Los aborígenes y los colonizadores europeos viven y crean paisajes bastante diferentes" (Morphy 1993:207).

En efecto, antagonismos étnicos, económicos y valóricos (de entre una amplia gama de conflictos posibles), pueden decidoramente ser enfocados utilizando el lente provisto por el "paisaje". Mientras permite eludir las turbulentas aguas geopolíticas de términos tales como "territorio", también evita los subentendidos impersonales de otras palabras como "medio ambiente" y "ecología". El "paisaje" parece siempre implicar la presencia o involucramiento de alguien, aunque sea tan solo como espectador.

La terminología del "paisaje", sin embargo, posee otras virtudes atractivas. Como demostraré, es un concepto "entremedio, libre de posiciones fijas, cuyo sentido elude, pero que potencialmente lo abarca todo" (Morphy 1993: 205). Es este mismo carácter elusivo que lo hace menos vulnerable de ser cooptado por discursos hegemónicos.

Adicionalmente, y como mencionara anteriormente, provee un buen marco no sólo para apreciar las luchas y conflictos del "Cuarto Mundo", sino también aquellos conflictos que en la actualidad oponen a los "eco-guerreros" y los Estados desarrollistas. Esta última, sin embargo, es una de las formas más conspicuas que suelen adoptar los conflictos en torno a los paisajes contemporáneos. Muchos, al margen de toda cobertura mediática e interés internacional, permanecen ocultos y/o son silenciados.

Este breve y sin dudas conjetural recuento de la "genealogía" del paisaje, podría ser considerado simplista, y ciertamente debiera ser llevado a cabo con mayor acuciosidad. Al investigar brevemente la emergencia y transformación de este concepto en la tradición antropológica, sin embargo, espero haber mostrado cómo y por qué el "paisaje" puede haber adquirido protagonismo analítico en debates antropológicos, ambientales y etnopolíticos.

\section{Desarrollo y paisaje}

Concuerdo con Jonathan Crush al entender el discurso del desarrollo como "una forma de escribir susceptible de análisis narrativo, en la cual la geografía es escenario y protagonista" (Crush 1996:14).

Indagaré sobre la utilidad de emplear la noción de "paisaje" para intentar entender corno se manipula la geografía y, las formas que adquiere en poder de discursos desarrollistas, y como esto a su vez afecta a la población humana. Si este discurso ejerce control, tanto sobre la "escena" geográfica (acepción limitada de "paisaje"), como sobre el guión (plan de desarrollo) y hasta el último detalle del décor, entonces poco queda para los actores o "extras" fuera de llenar sus papeles en la más predecible de las maneras.

En esta línea, Hugh Brody (1981) muestra cómo, a pesar de frecuentes afirmaciones en contrario, el discurso y la práctica del desarrollo suelen no acontecer en un ambiente social neutro. Brody logra exponer los choques de dos sistemas económicos que, aunque ambos viables, son, discutiblemente, incompatibles, y cómo estos conflictos son ocultados, desestimados o minimizados.

El impacto acumulado de la proyección onírica y económica del "hombre blanco" en la Columbia Británica de Canadá, por ejemplo, ha lentamente esculpido un paisaje en el cual los cazadores indígenas (en este caso los Beaver) no tienen cabida.

Este hombre blanco primero encerró a los indios dentro de límites físicos y legales claramente definidos por medio de tratados, reservas y territorios de caza registrados. Los territorios tradicionales indígenas restantes quedaron fuera de las sucesivas demarcaciones (y en adelante catalogados como terra nullius o tierra de nadie), para luego ser considerados como lugares que ofrecían posibilidades econó- 
micas ilimitadas, nuevas "fronteras" a la espera de ser abiertas. No se consideró importante el hecho de que los indígenas siguieran viviendo allí, como desde hace tiempos inmemoriales.

El proceso de registro de los territorios de caza a la larga también demostró ser un fiasco, pues el registro sólo protegía a los indios de otros cazadores, no de los agricultores e industrias mineras que lentamente iban adueñándose del espacio tradicional.

El modo de vida indígena fue simplemente ignorado: "Oro por tamizar, tierras a ser despejadas, paisajes de infinita expansión económica... Pero los sueños y mapas del hombre blanco son los augurios y señales de un futuro en el cual se espera que los indigenas no jueguen rol alguno" (Brody, 1981:115).

El discurso del desarrollo, basado en premisas económicas euroamericanas y considerado el único capaz de realista y eficientemente proveer a las necesidades humanas, es, así, en la práctica, expuesto como totalizador y excluyente.

En este contexto, es difícil imaginar como una reclamación indígena en pro de estrategias económicas endógenas podría ser escuchada -y menos aún respetada- en base al solo principio de preservar la diversidad cultural (económica).

En cambio, reclamaciones territoriales basadas en el paisaje, sea este simbólico, ritual o económico podrían demostrar ser más exitosas por el hecho de poder sustentarse sin entrar a cuestionar los paradigmas económicos euroamericanos.

Es más, dichas reclamaciones podrían estratégicamente fortalecerse de conceptos como los de "propiedad privada" o "conservación del medio ambiente". Cualquiera sea el caso, a Brody le queda claro que el empleo de nociones utilitarias como "uso de suelo", por sí mismas, no bastan para dar cuenta de la intrincada red de relaciones igualmente esenciales con la tierra que hace que los Beaver vivan en el modo único y distintivo en que lo hacen.

En este trabajo analizaré el paisaje atacameño como campo conflictual, y para ello se hace indispensable realizar el ejercicio foucauldiano de desconstruir, al menos en forma parcial, tanto el discurso del desarrollo como los presupuestos visualistas que subyacen a la terminología del "paisaje".

\section{Problematizando al paisaje: una crítica al visualismo euroamericano}

Algunas precauciones deben ser tomadas antes de utilizar al "paisaje" como inocente categoría analítica. Sus características estructurales e históricas re- quieren, previamente, ser consideradas con cuidado.

La etimología del "paisaje" ubica sus orígenes en la técnica pictórica renacentista, lo que explicaría por qué el paisaje es considerado, esencialmente, un artefacto visual. Intentos por definir este concepto en tonos universalistas se enfrentan generalmente a los límites que dicho origen Europeo implica, "pues hablar de "pintura" exige presuponer un "marco"." (Pinney 1992, citado por Weiner, 1997:2)

Tanto Barbara Bender como Hirsch parecen, sin embargo, estar de acuerdo en que el "paisaje", más que un artefacto o una realidad fijada, es un "proceso cultural" (Hirsch 1995:23), nunca inerte, siempre en construcción y reconstrucción. Decir, sin embargo, que el "paisaje" es una construcción cultural, no es decir mucho, y tan fácil generalización amerita ser cuestionada.

Hirsch nos dice que la construcción cultural del "paisaje" implica una relación entre el "primer plano" (la manera en que somos) y el "fondo" (la manera que pudiéramos ser) de la vida social" (Hirsch 1995: 3). Asumiendo que ésta constituye. una descripción válida para todas las culturas, él prosigue definiendo al "paisaje" como síntesis de un juego dialéctico de "primeros planos" y "fondos" generado por la colisión entre el "primer plano de la actualidad" y el 'fondo de la potencialidad" (ibíd.) (es decir, un choque de perspectivas espacio-temporales). Con esta afirmación, él demuestra adoptar nociones de tiempo lineal y una posición histórico-evolucionista respecto de la vida y tiempos sociales.

El 'paisaje', además, es concebido como ocupando un "luga" en el "espacio". El "espacio" objetivado es, sin embargo, otra categoría euroamericana no exenta de presunciones a exponer, incluso más difícil ele tratar que la del "paisaje". Se emplea como una especie de telón de fondo universal, contra el cual se proyectan y actúan los humanos. Hirsch inadvertidamente sustituye un tipo ele visualismo pintoresco, teatral (actores, escenario, guión) por uno de tipo cinemático, sin por eso contribuir a una mayor comprensión del "paisaje".

Casey explica, sin embargo, que "la experiencia del lugar no es una matriz secundaria que se superpone a la supuesta primacía del espacio. El 'lugar' es la forma más fundamental de experiencia corporal -el sitio de fusión de sujeto, espacio y tiempo". (Casey 1996: 9).

$\mathrm{Al}$ concebir al paisaje con una perspectiva lineal y evolucionista, Hirsch también revela un cierto etnocentrismo visual y conceptual. En efecto, una perspectiva lineal hace que tres (sino más) dinensio- 
nes sean reducidas a tan sólo dos. Además, la perspectiva no solamente organiza espacialmente a los objetos en el cuadro y congela el tiempo, sino que obliga, para dar vida al cuadro, a la presencia de un sujeto, un observador a quien ésta se dirige.

Así pues el "paisaje", aun aquel que podamos atribuir a una "perspectiva nativa" es un concepto limitado por su origen visualista y euroamericano. No es de extrañar, entonces, que muchos pueblos aborígenes (incluyendo al atacameño) no tengan equivalentes para esta palabra en sus lenguajes tradicionales.

Aún así, Bárbara Bender intenta evitar la trampa visualista al hacer un llamado todavía más radical a contextualizar el paisaje: "cada individuo sostiene muchos paisajes en tensión" (Bender 1993:2).

Tanto las posiciones de Bender y de Hirsch, en definitiva, inducen a cierta confusión, pues el "paisaje" de algún modo es tratado como realidad objetiva. Es descrito, por un lado, como un lugar que está permanentemente allí (aunque negociado, contestado, apropiado, construido o manipulado), $\mathrm{y}$, también, por otro, como lugar nunca alcanzado ni acabado, un lugar que en realidad no existe, un horizonte que siempre se aleja "algo siempre abierto a la renegociación" (Bender 1993: 276): un otro abstracto, elusivo.

Ambas posiciones, la radical de Bender y la de Hirsch, constituyen una "perspectiva de paisaje" (Hirsch 1995:23). No importa cuán arduamente intentan desobjetivizat la noción en análisis, invariablemente sucumben ante sus prejuicios visualistas, para caer en un perspectivismo renacentista.

Este visualismo perspectivista (y las premisas que lo subyacen), a mi juicio comparte características estructurales con el discurso del desarrollo. Analizaré la forma en que el discurso del desarrollo interpreta al paisaje, primero en calidad de "primer plano de actualidad", confundiéndolo con el mapa superpuesto de los recursos que éste contiene. Luego, mostraré como el mismo discurso redime al "paisaje" en cuanto "fondo de potencialidad", fondo sobre el cual un futuro mítico expresado en términos de desarrollo económico y progreso es a su vez inscrito.

Finalmente, sobre este punto, para acercarse al paisaje atacameño considero que no es sólo necesario contextualizar radicalmente, o desconstruir, sino que se hace indispensable "desaprender" el modo de mirar euroamericano, visualmente disciplinado. Esto se puede intentar con la ayuda de herramientas proporcionadas por la fenomenología.

\section{Hacia una fenomenología del paisaje}

Una hermenéutica fenomenológica, en la escuela de Heidegger, Husserl y Merleau-Ponty, puede agregar algunos elementos con los cuales pensar al paisaje y sus implicaciones.

No importa cuanto se diga que los paisajes son fluidos, relativos y culturalmente construídos, el hecho es que motivan maneras específicas de percibir. De algún modo son una realidad compuesta "allá afuera", esperando, por así decirlo, ser aprehendidas: "reconociendo la primacía de la experiencia sensorial, no es posible sostener que nos pone en presencia de un confuso caleidoscopio de datos sensoriales en vuelo libre. La "escena" observada tiene profundidad y horizonte, una coherencia proporcionada en el mismo lugar que ocupamos como sujetos sensibles. Lo percibido posee un centro de sentido inmanente, un "núcleo neumático", en la terminología técnica de Husserl" (Casey 1996: 17).

Utilizar la noción de que existen estructuras de pre-entendimiento, no sólo en la mente-cerebro (como cierta antropología cognitiva da por hecho), sino en las cosas mismas, parece ciertamente pertinente para entender la "agencia" que a estas "cosas" les atribuyen muchos pueblos indígenas. Este acercamiento permite comprender mejor el que los ríos hablen, y el que se les agradezca a las montañas por compartir. Permite también un involucramiento fresco, un cierto asombro ante las cosas como son, lo que a su vez posibilita el descubrir modos de ser y relaciones previamente indetectados.

De manera parecida, Marilyn Strathern nos dice que la "persona" melanésica se compone de modo diferente a la de los individuos euroamericanos. La persona melanésica sería más bien una relación, una instancia de ciertos motivos sociales (familiares, religiosos, económicos, políticos, etc.). Ahondaré más sobre este tema, pero en anticipación, y, llevando la hermenéutica de Strathern al análisis de las relaciones hombre-entorno, no resulta muy difícil imaginar a gentes que producen y reproducen sus identidades personales y sociales no solamente en relación sino que como relación con el "paisaje". Un "paisaje" que no es entendido sólo como sitio pasivo de memoria (un lugar en el cual la historia tan sólo se acumula) sino que un lugar que constituye una parte inseparable de una relación continua, recíproca y viva.

Así, arguyo que el pueblo atacameño y su "paisaje" no sólo están "mutuamente implicados" (Hirsch 1995:23), o "mutuamente envueltos" (Ingold 1992:51) por medio del devenir histórico. No sería apropiado 
considerar el uno como mero punto de referencia temporal del otro: en realidad el atacameño y su paisaje comparten su alteridad geofísica, humana o animal. Un análisis del modo de ver el inundo que tienen los atacameños, en el cual se considere a dicho modo como uno compuesto y realizado fractalmente, puede contribuir a elucidar algunos elementos menos evidentes de este involucramiento con el paisaje. Esto, no sólo para mostrar las conexiones entre hombre y paisaje, sino que, por medio del estudio de las relaciones adscritas, alcanzadas o establecidas, creadas o replicadas de otra manera, demostrar la identidad de ambos.

Utilizado con la prudencia sugerida, el "paisaje" puede demostrar ser una herramienta analítica de mucha utilidad en los debates antropológicos contemporáneos. Hace visibles una serie de fenómenos sociales previamente desapercibidos, y utilizado como un lente, permite enfocar una variedad de eventos y prácticas aparentemente desvinculados en un horizonte unitario de entendimiento. A pesar de las limitaciones expuestas, $\mathrm{y}$ a falta de una terminología más apropiada, la del "paisaje" puede contribuir, también, a esclarecer algunos de los problemas que surgen como consecuencia de la implementación de políticas de desarrollo.

Algunos de estos conflictos, generados en San Pedro de Atacama, permitirán explorar "las maneras en que la gente, diferencialmente comprometida y desde diferentes posiciones de poder, se apropia y contesta su paisaje" (Bender 1993:17).

\section{Planificación del paisaje y paisajismo}

El gobierno chileno tiene posiciones inequívocas respecto de la manera de llevar adelante el desarrollo del país. Esta visión estatal del desarrollo afecta a los atacameños debido a que el imaginario estatal es materialmente proyectado en el paisaje desértico.

\section{La "Estrategia Regional de Desarrollo": planificando el paisaje desértico}

El gobierno regional de Antofagasta, Segunda Región, Chile, dirigido por el Intendente, está aplicando, desde 1990, lo que ha denominado Estrategia Regional de Desarrollo (en adelante ERD), documento reputadamente aprobado por la "comunidad regional organizada"(ERD 1994: 6). En su primera parte, dicho documento hace un recuento de "La Región que Tenemos".

El tono "propietario" del texto es así manifestado desde el inicio, acompañado de consideraciones demográficas como la siguiente: 84,4 por ciento de la población total de la región de 410.724 habitantes estaría ligado a la actividad minera y viviendo en las zonas urbanas de Calama y Antofagasta. La población regional aparece compuesta por una mayoría de inmigrantes nacionales y extranjeros, y la "cultura regional" (ERD 1994:9) se caracteriza por el movimiento de las personas en búsqueda de mejores oportunidades económicas. El documento continúa describiendo a la población rural, indicando que ésta es escasa, de origen indígena "con una tradición once veces milenaria" (Ibíd.) y "perteneciente al mundo andino" (Ibid.). Más adelante es caracterizada corno dedicada a "actividades de subsistencia agropastorales" (lbíd.).

Los planes de desarrollo como el que examino comúnmente empiezan por dar una descripción geográfica del lugar a ser desarrollado. Efectivamente, "uno de los elementos primarios de la narrativa del desarrollo es poder establecer un escenario geográfico" (Crush 1995:14).

Timothy Mitchell denuncia concluyentemente estas caracterizaciones geo-demográficas. La imagería visual resultante contribuye a justificar el estudio y aplicación de un plan de desarrollo, que se insinúa como de necesidad absoluta: "la naturalidad de la imagen topográfica, tan fácil de visualizar, construye al objeto del desarrollo en precisamente eso, un objeto, allá afuera, no una parte del estudio sino que algo externo a éste. El discurso del desarrollo se constituye a sí mismo, de esta manera, en uno de expertos, de una inteligencia que se pone completamente a un lado del país y del pueblo que describe". (Mitchell 1995:130). Como señalé en la introducción, cuando el discurso del desarrollo hace equivalentes el paisaje y el mapa de los recursos que contiene, el discurso está también desligando al paisaje de sus moradores, arrancándole su carácter esencialmente relacional. Tal discurso no sabría negar que "los acercamientos al espacio desde la distancia, geométricos, "afuerinos", no pueden reclamar primacía sobre lo social y lo experiencial. La perspectiva única que ofrece podría ser la de un grupo dominante" ('Thomas 1993: 29).

Sólo es un cierto "paisaje" el que se hace aparecer, uno ligado a los intereses económicos de grupos y narrativas dominantes. Queda claro que "una perspectiva objetiva y distanciada del paisaje tiene mucho en común con estrategias de monitoreo y vigilancia" (Ibíd.). Las tecnologías políticas de control social pueden ser impuestas a través de diversos 
métodos de disciplinamiento, utilizando una variedad de técnicas: lo que llamaré "paisajismo" es sin duda una de ellas.

EL ERD, sin embargo, no sólo describe a la región en términos de los recursos que contiene, sino que acto seguido demarca y divide al territorio por medio de una incalsanble lógica dualista: "la oposición binaria entre lo desarrollado (territorios que tienen) y lo no desarrollado (territorios que carecen), creada por este ejercicio cartográfico resulta muy familiar" (Crush 1995:14). ${ }^{1}$

En efecto, esta lógica dualista le es también familiar a los planificadores del desarrollo de Chile. Los sectores urbanos y minero-industriales aparecen exhibiendo resultados y figuras impresionantes, una actividad económica pujante, un potencial enorme, y además, son caracterizados como conformando la raíz de la "cultura regional". Son desarrollados.

Por el lado opuesto, los Atacameños son marginalizados discursivamente, tipificados como perteneciendo a un mundo completamente separado, el "mundo Andino" (ibíd.). Son descritos como viviendo inmersos en una suerte de incambiable "tradición once veces milenaria" (ibíd.), llevando vidas poco productivas, calificadas como de 'actividades de subsistencia agropastoral' (ibíd.).

$Y$ luego, un comentario decidor: "aún cuando la infraestructura de transporte es adecuada y funcional considerando la actividad productiva regional, es insuficiente para la integración de las comunidades que están aisladas" (ibíd.:11, énfasis mío). El gobierno regional está implicando, inadvertidamente, que las comunidades indígenas 'aisladas': a) no participan en las actividades productivas de la región, y b) que estas comunidades, sin embargo, requieren ser 'integradas'.

1 Sobre este punto sea tal vez útil recordar la descripción que Said hace del 'Orientalismo', de patrón similar: el de un discurso a través del cual el 'Tercer Mundo' es administrado y producido a través de un disciplinamiento sistemático. El disciplinamiento es logrado mediante la repetición de 'rituales cte verdad' y, en el caso del discurso del desarrollo, es respecto de la necesidad de pavimentar el camino para alcanzar las condiciones que caracteriza a las sociedades ricas: industrialización, modernización agrícola y urbanización. Empleando los dramáticos términos de Escobar: "El desarrollo coloniza la realidad, se vuelve realidad." (Escobar 1995:214).
El Estado reconoce en la construcción de carreteras, una efectiva tecnología política, y manifiesta su voluntad de usarla. Y la construcción de carreteras es ciertamente una de las actividades que más interviene los paisajes, un tipo de "paisajismo" cargado de consecuencias.

\section{Paisajismo}

El "paisajismo" comparte patrones estructurales con el "disciplinamiento" y otras tecnologías políticas descritas por Foucault. Esta tecnología presupone el reino de una "civilización especular" (Thomas 1993:22) y es un concepto que se puede relacionar con el Panópticon de Jeremías Bentham (Foucault, 1984: 201), una metáfora para describir el poder con el cual el Estado crea un "paisaje" pintoresco que se puede mirar, pero que no devuelve la mirada.

El término "Paisajismo" no es, sil embargo, sólo útil para denotar la preponderancia de lo visual, sino que describe una estrategia particular de control social, concebida en el marco de una "política de la visión" (Thomas, 1993:22) específica. Dicha estrategia parece operar a través de dos mecanismos. Primero, el discurso del desarrollo presenta un paisaje inerte, un conjunto de recursos aprovechables o no, desarrollado o a ser desarrollado. Un escenario social en blanco, un espacio para ser tomado (o a ser 'inte-grado') es comúnmente presentado a los ojos de la mente.

Esta operación discursiva deshace todas las relaciones con un entorno dado, que no estén bajo el signo del utilitarismo: "Presenta al mundo desde el punto de vista del afuerino, (el paisaje) toma el rol pasivo de objeto, representado, manipulado y alienado, negando cualquier agencia propia" (ibíd.).

Los planes de desarrollo, sin embargo, después de minimizar el paisaje que precede la intervención, generalmente traen a la vista poderosas imágenes de un posible "paisaje" (desarrollado), un "paisaje" que, descrito como con un pasado sin importancia, se convierte en un "lugar de visiones de un futuro trans-formado" (Morphy 1993:213).

El discurso del desarrollo es por lo tanto equívoco, por que, por una parte, "en muchos planes de desarrollo, la geografia es principalmente un inerte inventario espacial de hechos físicos v sociales" (Crush 1996:15), y por otra, el discurso del desarrollo presenta su propio imaginario ole un "paisaje" idílico, modernizado. Sí, "el idioma del desarrollo también trae un conjunto de poderosas imágenes paisajisticas a la vista" (ibid.): aquellas de un paisa- 
je "desarrollado", "modernizado", uno que no parece admitir alternativas.

En el ERD, este conjunto de imágenes de un paisaje desarrollado -que compondrían aquello que Hirsch denomina el "fondo de potencialidad"- son presentados al público en el siguiente capítulo del texto en comento: "La Región que Queremos"(ERD) 1994:13). En esta parte, el ERD empieza por recordar al lector que, para hacer posible el desarrollo de la región, "el Estado debe conservar la capacidad de regular el proceso -en su misión de velar por el bien común- pero debe hacer un esfuerzo para establecer instituciones eficientes que demuestren capacidad para el control, promoción y conducción del proceso de desarrollo" (ibíd.:15).

Con algunas salvedades, los objetivos "regionales" están expresados en términos extremadamente vagos. Uno de aquellos descritos con detalle y claridad es aquel que señala que la región será transformada "en un eje de integración e intercalibio comercial, con la construcción del Corredor Bioceánico del Norte Grande" (ibíd.: 16).

La carretera pasará por el principal asentamiento Atacameño, San Pedro de Atacara. El gobierno regional ha manifestado el claro deseo de transformar al lugar en un sector de servicios. Los miles de camiones que utilizarán esta carretera (Paso Jama) que conectará al norte de Chile con Argentina, Paraguay y Brasil podrían tener un puerto seco en San Pedro de Atacara. El cambio de "actividades de subsistencia agropastorales" por otras asociadas al servicio de camiones, es seguramente a lo que se refiere el gobierno regional, cuando como se dijera más arriba, desea "integrar a comunidades aisladas" mediante una mejor 'infraestructura caminera y de transportes".

Pero el estado también tiene planes etnocéntricos para enfrentar una agricultura problemática, actividad principalmente desarrollada por indígenas: "a) incentivar la producción, a través de una transfor-

2 Por supuesto que el interés por cl agua es comprensible. y el gobierno señala que es un objetivo regional prioritario el (ERD 1994 :22-23). La urgencia ele esta demanda ha significado la casi completa desaparición de poblados indígenas corno Cupo, Ojos de San Pedro, Paniri y Toconce (CONSECOL 1988). mación agrícola, orientada al mercado regional; b) incorporar cultivos de alto valor agregado, para la exportación; c) plomover la participación $y$ entrenamiento del pequeño agricultor para que así éste pueda integrarse al proceso de desarrollo tecnológico; d) dar agua suficiente para el desarrollo de la actividad agrícola, que pueda generar mayor calidad de vida. Esto significa superar la agricultura de subsistencia; e) Introducir tecnologías de irrigación que permitan un uso más eficiente de las aguas, aumentando la productividad' (ibíd.:21-22)2 .

Más allá de un evidente etnocentrismo, es sorprendente averiguar que el estado 'dará agua' a los atacameños para la agricultura, como si no la tuvieran ya, y desde hace milenios.

\section{La "dictadura" del desarrollo}

Imaginemos, por un instante, al "paisaje" como un campo conllictual, un lugar en el cual las narrativas dominantes intentan inscribirse en un estrategia que busca que éste refleje sus historias propias y exclusivas. En el caso del discurso del desarrollo, este "paisajismo" consiste en permanentemente inscribir el proyecto modernizador. Pero a través de las políticas de desarrollo y la modernización del paisaje, el Estado chileno también está programando modos de ser-en-el-mundo.

La creación de cierta forma de localidad o "lugar" por parte del discurso del desarrollo es parte del proceso estatal de colonización interior. En Chile, es claramente una manera de responder al problema geopolítico que plantean las "fronteras interiores" identificadas por la "intelectualidad" militar. Estos han sugerido que los territorios en cuestión y sus poblaciones indígenas ("conquistadas" a Bolivia a fines del siglo pasado) sean efectivamente integradas al Estado-nación chileno a través del desarrollo económico.

Chile puede así caracterizarse como uno de aquellos países que intenta trabajar "el proyecto ilustrado de la participación política, basado en la idea de un individuo educado, post-étnico y calculador, que subsiste en base a operaciones de libre mercado, $y$ que participa en una sociedad civil genuina" (Appadurai 1996:142).

Se suele pensar que una sociedad civil sólida puede evitar o alejar los desórdenes generados por discursos políticos esencialistas (en el caso de Chile, por ejemplo, hubiera podido evitar los excesos del gobierno socialista de Allende y su secuela golpista). El actual modelo de sociedad civil, sin embargo, es 
agresivamente pro capitalista, evidente y activamente contaminado por la influencia de los Estados Unidos de Norteamérica en varias formas de subsidio económico, político e ideológico. El supuesto éxito que habría tenido Chile al sobrellevar los primordialismos ideológicos, difícilmente puede ser considerado un logro derivado de la vitalidad "endógena" del programa de la Ilustración. Una gran dosis de "autoritarismo" fue también necesaria (para seguir la sutil distinción que Jeanne Kirkpatrick hizo entre estados autoritarios y totalitarios).

En el caso de Chile, el "vacío cultural" generado durante el régimen militar, requisito que se estimó indispensable para construir una dócil y "genuina sociedad civil", ha derivado en un Chile con un alto nivel de intolerancia, dónde la libertad de prensa y expresión son disfrazados por la retórica del Estado, y un pensamiento único parece regir los destinos del país.

El resultado de la estrategia dictatorial fue la homogeneización. Los militares alcanzaron sus objetivos geopolíticos: isomorfismo de estado, nación, territorio, mercado y, finalmente, individuos orientados hacia el mercado. Y, sin embargo, el paisaje aún no ha sido plenamente "modernizado". Para ello necesita, en forma previa, ser domesticado, manipulado y controlado a fin de que pueda reflejar -y ser isomórfico- al resto.

La renovada democracia chilena, a través del discurso del desarrollo, ha retomado el legado militar: este proceso se hace visible al mostrar sus influencias en el paisaje.

Un proyecto de "paisajismo" sería uno en el cual maneras de ser-en-el-mundo culturalmente específicas son creadas o impuestas desde un poder con pensamiento único. Estimo que la domesticación del "paisaje" por parte del discurso del desarrollo es también la de la gente que con él se relaciona. Más allá de los efectos alienadores que pueda tener la creación de espacios de tipo urbano (poblaciones), el discurso crea "una manera distintiva de mirar, a ser desplegada hacia los lugares, como lo es hacia otros fenómenos". ('l'homas [993: 20): la manera de mirar de los individuos orientados hacia el mercado. Por supuesto, ni el lenguaje de la "integración económica", junto a aquel del "interés nacional"; ni los efectos que éstos tienen en el paisaje, forman parte de una tecno-logía política recién descubierta. Sin embargo, debido al aislamiento de los oasis, a cierta hostilidad del desierto, y al modo de ser Atacameño, los efectos visuales de dichas políticas han sido temporalmente evitados. A pesar de que existe gente que cree que el paisaje andino "es el último e indes- tructible Ícono religioso -símbolo del Ayllu mismo" (Allen 1988: 33), la intervención de mega-proyectos como los de las represas y carreteras, repetidamente demuestran el poder avasallador del "paisajismo" moderno. Los impactos en la cuenca del Salar de Atacama jamás habían sido tan grandes.

\section{Paisaje y cosmología atacameña}

\section{Algunos reparos históricos a propósito de un cliché euroamericano}

Para el ojo mental del euroamericano, el paisaje que rodea a San Pedro de Atacama aparece compuesto de altas montañas que dominan un inmenso desierto, un mar de sal, rocas y arenas, aquí y allá manchado por el verde insular de algún oasis.

La claridad y luminosidad del aire y cielos desérticos acortan distancias y aplanan la tierra iluminada por el sol. Las montañas llaman la atención, señoreando por lo alto, con una suave caída de detalles hasta la planicie.

Desde cada uno de los pueblos, la gentil curva de las pendientes puneñas puede ser observada a ojo desnudo a lo largo de un centenar de kilómetros y más -la cumbre nevada del Llullaillaco puede verse refulgir a cerca de doscientos kilómetros hacia el sur de San Pedro.

Con excepción de los pastizales, exhibiendo sus tonos verde amarillos sobre la línea de los 3.500 metros, no se distingue vida alguna. Desde el valle y el poblado, este "paisaje" que los atacameños llaman Puna, parece uniformemente seco y resquebrajado.

Un ojo foráneo tal vez retenga la belleza impresionante de la cordillera de los Andes, y la claridad con que los cerros y volcanes se recortan del cielo azul y cristalino, mientras un manto de lava terciaria se va curvando dócilmente para finalmente descansar en el llano.

Quizás, entonces, uno de los millares de turistas (por cierto, la mayoría de origen Euroamericano) que anualmente va a San Pedro de Atacama recordaría su asombro ante la verticalidad masiva de la montaña y la curvatura uniforme de la Puna. Los atacameños, sin embargo, los habitantes de este maravilloso escenario natural, son invisibles, apenas parecen existir.

En un intento por agregar algo a esta noción cliché del paisaje, Hirsch tal vez incorporaría la temporalidad ideal de la "historia" a la perspectiva espacial bi-dimensional (que no es puesta en cuestión). De esta manera, la "implicancia mutua de gente y tierra" se haría visible. 
Siguiendo una línea argumentativa similar, aunque hablando de "perspectiva de morada" (Ingold 1995:58), Tim Ingold señala que "percibir el paisaje es llevar adelante un acto de memoria... involucrarse perceptivamente con un entorno preñado de pasado" (Ingold 1993:152-3). ingold habla, objetablemente, de "percepción" y de "pasado", en una manera que parece dar por hecho modos de relacionarse y concebir tanto el tiempo como el espacio, manteniendo, en esta forma, una dicotomía que una fenomenología consecuente haría colapsar en el "lugar" (del cual el paisaje es sólo una careta):

"El lugar no es solo unificador, también desconstruye las oposiciones que trae y sostiene juntas en su propio ambiente. Estas oposiciones incluyen pares binarios de términos que han gozado de poder hegemónico en la epistemología $\mathrm{v}$ metafísica occidental, como las de sujeto y objeto, uno y otro, formal y sustantivo, mente y cuerpo, percepción y memoria (o imaginación), e incluso el de naturaleza y cultura"(Casey 1996 :36, énfasis agregado).

El "paisaje" procesal mencionado más arriba es, sin embargo, mucho más directo, continuo y complejo que eso. Un "paisaje" no es sólo gente y tierra constituyendo inscripciones espacio-temporales, hitos o puntos de referencia el uno para el otro. Es cuestionable, además, atribuir a la concepción lineal euroamericana de historia, un carácter de absoluto, esto es, como "pasado". Al hacer esto, Hirsch e Ingold excluyen la posibilidad de que otras narrativas o historias sean vividas, creadas, representadas, escritas, descubiertas, olvidadas o ignoradas en relación con cualquier entorno dado.

A pesar de haber Ingold recientemente manifestado su voluntad de superar un "dualismo cartesiano no reconstruido" (Ingold 1995:58), y de sus intentos por adoptar un "postura fenomenologica amplia" (ibíd.) que pudiera contribuir a evitar la "orientación cognitivista. del psicologismo dominante" (ibíd.), él sin embargo cae en aún otro tipo de etnocentrismo. En efecto, intentar alcanzar un mejor puesto de observación, escalando dimensiones intelectuales agregadas (en este caso, las nociones reificadas de historia y espacio), sigue suponiendo la presencia de un observador que esté fuera o por encima de aquello que es observado. Una fenomenología consistente debiera enfrentar los problemas de representación.

\section{La Puna de Atacama}

El entrecruzamiento de riachuelos aparentemente secos, rayando la Puna de Atacama en realidad son cientos de quebradas. En contraste con la mirada pintoresca que describí al iniciar este capítulo, Pacífico Mondaca o Celestino Cruz, de Toconao, aún pueden recordar el nombre de la mayoría de estas quebradas casi deshabitadas, la calidad y sabor del agua que fluye o filtra por ellas, y, lo que crecía en sus ahora abandonadas terrazas. Para ellos, las quebradas también son los límites visibles de tierras de pastoreo claramente definidas, y ahora, secas. A una distancia de más o menos treinta kilómetros, ellos pueden decir qué extensiones de la Puna (entre ésta y aquella quebrada) pertenece aqué familia. Ocasionalmente alguno de ellos hará un largo viaje para visitar un pariente que aún vive de tres o cuatro melgas y algunos animales, solo, en la quebrada de Celeste. Un poco mas abajo por la quebrada, el $\mathrm{Pu}$ kara de Zapar domina cientos (le terrazas que yacen abandonadas.

La Puna está viva, pujante de una vida oculta a los extraños. No habla de su "historia" sólo como pasado, y es más que mera parte integrante de la memoria atacameña.

El "paisaje" es un efectivo co-participante en el flujo y construcción diaria de la vida atacameña. No es solo un grandioso escenario, cargado de significado histórico. Tampoco, sin embargo, es vivido como el paisaje de los aborígenes australianos, testimonio permanente y móvil del recorrido cosmogónico efectuado por animales totémicos y antepasados (las Huellas del Sueño).

Para el atacameño, el "paisaje" quizás sea vivido más como socio, pariente y panteón, una más de entre un número ole "formas hologrólicas" (Wagner 1991:166) de relaciones de parentesco, sexuales o de jerarquía (entre otras). En realidad no es un paisaje en absoluto. Ejemplificaré esta afirmación por medio del análisis de la "montaña" o "cerro", concepto que sobresale en las descripciones euroamericanas del paisaje y pensamiento atacameños.

\section{Visión del mundo atacameña y el paisaje fractal}

Mi acercamiento a este tema está inspirado en el trabajo de melanesianistas como Roy Wagner y Marilyn Strathern, y el uso que ellos hacen de la metáfora matemática de los fractales. Considero que ésta contribuye a entender la composición del modo de ver el mundo que tienen los atacarneños y andinos en general. También contribuye a evitar las limitaciones de modelos dualistas (o, para el caso, tripartitos o cuadripartitos) tan utilizados por los expertos en 
estudios andinos. Aunque de extrema utilidad para empezar a entender algunos fenómenos sociales, estos últimos acercamientos permiten describir tan solo algunos de los aspectos más sobresalientes de las cosmologías andinas, y le dan un carácter de perfección arquitectónica que no tienen. Aún de existir algo tan reificado como una "cosmología andina", parece que ésta resistiría verse abarcada y reducida por un análisis binario. Muchos fenómenos parecen entrelazarse siguiendo patrones más intrincados, cambiantes y de múltiples niveles de lectura posible.

Los acercamientos a las cosmologías andinas se han generalmente intentado utilizando conceptos focales tales como "dualidad", "coca", "Ayllu", "pacha", "montaña", "estrellas", etc., cada uno de estos términos considerados fundamentales para su comprensión ${ }^{3}$. En los Andes, sin embargo, ninguno de estos motivos recurrentes puede claramente disociarse de los otros. Al contrario, cada uno de ellos se define en términos de la malla de relaciones en la cual está entretejido con el resto. Se realizan fractalmente, "es como si sus relaciones fueran también ellos mismos" (Strathern 1995:250), Por definición, se constituyen relacionalmente ¿Pero de qué están hechas estas relaciones, cuál es su "materia"?

En vez de explorar las posibles maneras en que una "persona fractal" andina pudiera surgir de su entorno social, sin embargo, extenderé el uso de la metáfora de los fractales para analizar las relaciones sociales que se encuentran más allá de la sociedad humana, en el entorno no humano, particularmente el "paisaje" atacameño y sus diversas componentes. Es un modo de estudiar las cosmologías andinas que implica extender las características de la sociabilidad al entorno geofísico, para de esta manera acercarse más al modo de vida atacameño, a sus conocimientos del entorno y sus relaciones con él.

\section{Verticalidad y la montaña fractal}

Parafraseando a Wagner, entiendo que la montaña atacameña "no es nunca una unidad relacionada a un agregado mayor, o un agregado mayor relacionado con una unidad, sino que es siempre un entidad con relaciones integralmente implícitas... (es) una de un número de instancias de una integralidad de

3 Ver Bastien (1978), Isbell (1978), Urton (1981), Platt (1986), Allen (1988). relaciones" (Wagner 1991:163).

Consideremos al "paisaje" atacameño como uno que es realizado fractalmente. Es, pues, esencialmente relativo y relacional, no sólo para el observador atacameño, sino que considerando los diversos elementos que se dice lo componen (montañas, ríos, puna, quebradas, etc.) Siguiendo con la hermenéutica de los fractales, se podría hacer aparecer a estas relaciones estableciendo, inicialmente, los términos que la componen: no importa cuantas veces un fractal sea dividido o multiplicado, retendrá su escala, su definición relacional.

Lo que se debiera encontrar, entonces, es "una figura que conserva su complejidad a través de todas las escalas de disminución o agrandamiento" (Strathern 1994:250).

Como punto de partida para buscar a qué se podría parecer uno de estos "motivos" o "figuras" relacionales y relativas, reconozcamos que la verticalidad es "un principio que subyace la organización económica, politica y social andina" (Murra, citado por Bastien, 1978:xxiii). Más allá de una interpretación meramente materialista (v.g. una estrategia para el control de nichos ecológicos distintos, determinados por el factor altura), es dable suponer que dicha "verticalidad" tiene repercusiones e implicancias cosmológicas.

Imaginemos, entonces, una línea vertical y ascendente, trazada para unir -en sus crecientes grados ele inclusión- cuerpo, casa, Ayllu, "paisaje" y cosmos (estrellas). Empleando la metáfora de los fractales, consideremos a cada uno de estos conceptos como una proyección holográfica específica de ratios valóricas congruentes, a distintos niveles de ampliación (o miniaturización).

Tal vez las palabras de un vecino atacameño puedan explicarme mejor: "todas las cosas son como las pieles de una cebolla" (Carlos Aguilar, Solcor).

Cada una de estas "pieles" es una instancia más de una serie de mallas relacionales congruentes, $y$, aun si para el ojo extranjero aparecen como fenómenos claramente distinguibles, los atacameños se relacionan con cada uno de ellos como con réplicas magnificadas (o miniaturizadas) de un conjunto recurrente de relaciones, o "motivos fractales" (Wagner 1991:170). Las relaciones se entablan como en una sala de espejos cosmológica, en la que ciertos motivos recurren con mayor claridad que otros.

La pregunta surge de nuevo. ¿Cuáles son las relaciones y motivos recurrentes que se realizan así, fractalmente?

El cuerpo humano, como centro de la experiencia 
sensorial, debiera ser uno de estos "términos de relación" ubicados en esta línea imaginaria vertical que une diversos órdenes ele magnitud, un locus hacia o desde el cual diversas (aunque íntegras) proyecciones relacionales se concentran, o son, por así decirlo, "emitidas".

Motivos de tipo fractal debieran "encontrarse" al estudiar el modo en que la subjetividad atacameña se podría componer a través de estas relaciones. En la misma línea, Bastien, por ejemplo, da una idea de como la subjetividad de los Kaatanos podría componerse al afirmar que ellos "entienden a la montaña como cuerpo humano" (Bastien 1978:43).

De conformidad a lo que vengo argumentando, sin embargo, los motivos fractales podrían hacerse aparecer al analizar cualquier término ele relación en las relaciones dadas.

Así, y sin negar la importancia de las concepciones que los atacameños puedan tener respecto del cuerpo, prefiero centrar mi análisis en aquellos conceptos andinos polisémicos. que, como la montaña, están más directamente vinculados al tema que trato, el paisaje.

\section{Montaña, Ayllu y Pachamama}

Las palabras andinas "clave" proveen excelentes medios para elucidar los ratios de valor que recurren fractalmente. El modo de ver el mundo atacameño se articula con conceptos como pacha, Ayllu, montaña, y ancestros. Muchos atacameños, pero especialmente los llatires (especialistas rituales o chamanes), tienen cierta claridad respecto de las profundas implicaciones y traslapes cosmológicos que están en juego.

Bastien señala que "los Andinos están unidos por concepciones culturales compartidas respecto de la montaña" (Bastien 1978:xx) y abundante etnografía ha demostrado este hecho. No es, entonces, sorprendente encontrar que, en el extremo sur del altiplano Andino, las comunidades atacameñas tengan cerros tutelares o sagrados. Bastien considera que la importancia cultural de la montaña es una demostración, a nivel cosmológico, de la validez del principio de la verticalidad.

La verticalidad por sí misma, sin embargo, no explica suficientemente la importancia que los andinos le atribuyen a las montañas, que encarnarían "una metáfora holistica y unificadora" (ibíd.:xix). Luego, Bastien señala que "aún más básico que la verticalidad, está el Ayllu, entendido como una mezcla de lazos territoriales, simbólicos, $\mathrm{y}$ de parentes- $c o "$ (ibíd.: xxiii).

Se suele gralicar la relación entre montaña y Ayllu con una pirámide, réplica de la estructura social, cuyo ápice está formado por los líderes, y cuya base está formada por el pueblo común.

Desde un punto de vista diferente, sin embargo. la base social (o ayllu) puede ser imaginada como línea horizontal en relación a la montaña, que es vertical: juntos, estos dos elementos formarían una cruz, también imaginaria, que Urton sostiene es "un importante principio de organización cosmológica (andina)" (tlrton 1981 :129). Un motivo fractal. Pero el Ayllu mismo, de manera congruente con la. hipótesis planteada, no es exclusivamente concebido como horizontal. Existe tanto un Ayllu de jerarquía, en la línea vertical de descenso, como un Ayllu horizontal, de lazos de afinidad (Allen 1988:103). El Ayllu mismo configura una cruz. Urton, en armonía con lo expuesto. demuestra que este mismo motivo es replicado en nociones andinas de astronomía, diseño urbano (Misminay), patrones decorativos, utensilios de cocina y cosmología general.

Esta cosmología ele congruencias y yuxtaposiciones se manifiesta también en las creencias respecto de los ancestros: ellos son las montañas. El Ayllu es la familia viva, pero "Ayillu también significa que, al igual que la montaña, una familia tiene un ancestro" (Bastien 1978:xxiv). Y este ancestro es el mismo para ambos, hecho demostrado en diversos rituales de Ayllu que son, en las palabras de Bastien, "un proceso que permite a esta gente expresar, por medio de símbolos, su unidad con la montaña. Ellos la alimentan (ritualmente) y se la comen. Ellos se hacen montaña y la montaña se convierte en ellos mismos" (ibíd:xxv, énfasis original). Ritos de abundancia asociados a los ancestros del ayllu vivo y a la montaña, a los Tatas, que dan la vida con agua, semen, con sangre, sombra.

En Atacama, esta identidad entre ancestros y montaña es expresada en muchos rituales: el carnaval y su Catimbano, por ejemplo, el baile más antiguo vigente en San Pedro de Atacama. Este baile es liderado por los "Achaches", nombre aimara usado tanto para designar a los "ancestros" como a los espíritus de la montaña. Con plumas de Suri sobre sus espaldas, y látigos, reconocidamente representan a los ancestros, "abuelos" o "gentiles" (ancestros no bautizados)" (Núñez, 1992:166). El rol de Achache es desempeñado por los miembros de más edad de la comunidad.

Bastien, sin embargo, a veces parece implicar que montaña y pueblo son sólo idénticos de manera metafórica o simbólica: "La religión Kaatana no es 
conceptual ni contiene un mundo de espíritus, sino que es una relación metafórica con su tierra" (ibíd.) ¿Por qué metafórica? Cierta tensión se hace manifiesta entre, por una parte, la interpretación de Bastien, y, por otra, el hecho de que los kaatanos identifiquen realmente sus cuerpos y relaciones con los de la montaña. Sobre este punto concuerdo con Pascal Boyer, en cuanto al limitado valor explicativo de la palabra "metáfora", puesto que esta palabra "es en sí una metáfora" (Boyer 1994: 55) y que "al decir que el simbolismo religioso es una construcción metafórica (que la noción de orden cósmico en cierta tribu, por ejemplo, no es más que una metáfora respecto del orden social), se sugiere mucho pero se demuestra muy poco" (ibíd.). Es posible que, de nuevo, una mirada fenomenológica puede interpretar mejor el lebenswelt atacameño (o kaatano): así, la "religión" atacameña es una relación íntegra con su paisaje.

Pensando con la ayuda de los fractales, las relaciones entre gentes, aquellas entre montañas y las de las unas con las otras aparecen como congruentes (una y la misma), una identidad que se mantiene a través diversos órdenes de magnitud.

Los atacameños comen (de) su tierra, y son lo que comen: "...esta tierra es mis huesos, esta agua, mi sangre" (Don Víctor Berna de Toconce, citado por Castro 1994:73). La tierra se los "come" a ellos, y es a ella que ellos se comen. Son más que una "montaña humana" (Bastien 1978:43) a nivel metafórico.

Los ancestros andinos, el Ayllu y la montaña se viven como réplicas unos de otros, son el uno el otro en la medida en que las relaciones en la cuales participan son idénticas. Esto es sin duda explica por qué Allen caracteriza al paisaje andino y su gente como "sociedades paralelas cuyas relaciones son sacadas a luz en los rituales" (Allen 1988:32).

Las relaciones son alimentadas por medio de la reciprocidad y más o menos solemnes rituales de intercambio, a menudo reconocidos como centrales en el contexto andino. Esto lo ilustra muy bien el hecho de que las ofrendas que se hacen a la montaña son llamadas "pagos".

Las relaciones de reciprocidad con el paisaje son alegóricamente representadas, por ejemplo en el pago ritual de los favores que se le piden a la montaña (y que también le son pedidos a los ancestros y a la Pachamama). En la ceremonia del Talatur, como todavía se realiza en el pueblo atacameño de Socaire, el Cantal (que es especialista ritual y chamán) llama a cada montaña por su nombre, pidiéndole agua, para que la deje fluir y dar vida.

\section{Paisaje jerarquizado y orden cósmico}

La toponimia es también un modo de expresar la manera de ver el mundo, y, generalmente, los nombres locales de lugares y lugarejos "cuando son empleados en ciertos contextos, contribuyen a la creación de sentidos de lugar ricos en texturas morales, cosmológicas y biográficas" (Feld y Basso 1996:9).

La familia más prominente de algún pueblo atacameño puede llevar el nombre del cerro que lo tutela. Así, del pueblo de Paniri, que yace a los pies del volcán homónimo (Mayllku Panire), provienen los nombres de importantes líderes atacameños.

Los nombres andinos son polivalentes y polisémicos, pudiendo así cumplir diversos roles en el lebenswelt atacameño. Parafraseando a Roy Wagner, los nombres de las montañas son más grandes que las propias montañas. Como lúcidamente lo explica, "el otorgamiento de un nombre es siempre una manera de fijar un punto de referencia de entre un rango potencialmente infinito de relaciones, una designación esencialmente relaciona/" (Wagner 1991:176).

La congruencia de montaña y nombres de familia no es, entonces, accidental. Del mismo modo en que la montaña protege al valle y bisagra el orden cosmológico, el líder es esencial para la sustentación del orden social. Las jerarquías cosmológicas y sociales se replican.

El principal volcán a erguirse sobre la cuenca del Salar de Atacama es el Licancabur, palabra kunza para designar al "Cerro del Licán", a menudo traduciéndose esta última palabra por "pueblo" (Lehnert 1994:43) o gentes. El cerro del pueblo es también conocido como señor del pueblo. Este nombre es explícitamente relacional. Establece la posición de liderazgo del volcán (y por fenómeno de réplica, la del líder atacameño) sobre los demás, cerros y humanos por igual. Además, encarna físicamente (y típicamente) a los ancestros, los Achaches (o Achachilas) y Wamanis o Mallkus y Apus. Las montañas son presencias permanentes, inamovibles y ancestrales. Pero son también activas dadoras de vida, porque son las montañas las que guardan y distribuyen el agua (en la medida en que hayan sido realizados los pagos apropiados). Usando la terminología de Suzanne Kiichler, las montañas no son estáticas, "de la memoria", sino que "como memoria" (Küchler 1993 :86), un proceso de compartir.

\section{Paisaje de géneros y reproducción. social}

Una lectura adicional del nombre Licancabur nos habla de su masculinidad. Un relato mitológico 
Atacameño habla del macho Licancabur, que tiene por esposa al Kimal (la más grande y extensa montaña de la cordillera de Domeyko, paralela a los Andes), la que yace como su contraparte femenina.

Esta versión es particularmente interesante, pues muestra una relación que configura un patrón idéntico que se replica en aquel de las relaciones entre hombre y mujer, macho y hembra, vertical y horizontal, montaña y ayllu o Pacha.

Considerando al "paisaje" en relación a sti género (grosso modo, Mallku y Pachamama), las sombras (como el agua) juegan un importante papel mediador. La cordillera de los Andes corre por un eje Norte-Sur casi perfecto, y la sombras que el sol y la luna producen constituyen siempre una presencia decidora: apuntan hacia cosas. Se dice que en cierto día del año (29 de junio, que coincide con el solsticio de invierno), el sol se levanta detrás del Licancabur, y que, mucho antes de que sus rayos puedan ser vistos desde el valle, la sombra cónica del volcán se proyecta a través del desierto hacia la cordillera de Domeyko. Se mueve hacia el Kimal para cubrirla. Algunos dicen que copulan, que la tierra es fecundada: se inicia un nuevo ciclo agrícola.

Montaña, agricultura y gente, todas tornan parte de un único patrón reproductivo.

Pienso, sin embargo, que categorizaciones dualistas estrictas explican en forma limitada los roles y posiciones de género atribuidos a los Mallkus y a la Pachamama. Cada montaña, además, es a la vez sí misma y las relaciones que comparte, "masculinidad y feminidad no se yerguen en posición rígida la una contra la otra. Una entidad dada puede ser considerada masculina en algunos contextos y femenina en otros" (Allen 1988: 49).

Si bien es cierto que las montañas son generalmente consideradas de género masculino (en relación a la horizontalidad de la santa madre tierra Pachamama), no lo es menos que: a) los cerros y montañas son parte de la Pachamama, y b) cada comunidad atacameña identifica a dos cerros tutelares en su territorio, uno hembra y otro macho (Ernesto Contreras, comunicación personal).

\section{Pachamama}

El término Pachamama es también de compleja naturaleza polisémica, y es empleado para expresar niveles cosmológicos diferenciados: significa simultáneamente, a) "el cosmos que lodo lo abraza o Madre Tierra" (Núñez 1994: 238), lo que confirma un Cantal Atacameño: "todo es uno: Mallkus, aguas y Pachamama" (el Cantal Horacio Morales, citado por Grebe 1990 :47), b) la materialidad del mundo "el terreno o suelo plano" (Allen 1988:49) y; c) "lugar" (Castro 1994:102). Es comúnmente referida colmo a una madre, una mujer.

Conceptos andinos claves como éste claramente condensan nociones de verticalidad y horizontalidad, masculinidad y feminidad: la Pachamama es integradora. Puede estar completamente involucrada en cualquiera de sus aspectos mencionados, y según el contexto, sagrado o no, en que se la invoque.

De nuevo, un solo nombre (fractal) es usado para expresar niveles cosmológicos diferentes que pueden considerarse versiones reducidas o ampliadas de un solo motivo o idea.

El conocimiento andino al respecto es recogido en la afirmación efectuada por Bastien en el sentido de que "La tierra y los humanos ya no existen como dicotomías, sino que son más bien reflejos sin fin de espejos con formas diferentes. No hay necesidad de buscar lo que distingue a la tierra de los humanos, puesto que son esencialmente idénticos" (Baslien 1978:56).

\section{Ritual, intercambio e unidad}

Cuando le preguntaba aSimón Tito(Ayllu de Solcor), vecino de edad y reputado llatire, respecto de su cosecha, él me decía que los choclos no se daban como antes, puesto que ahora, nadie hacía los pagos apropiados, ofrendas de aloja, chicha y coca a los abuelos y a la Pachamama. Por eso, decía, la tierra estaba seca e improductiva. Ya no se respetaba a la Pachamama, ni se le rendían honores a los Mallkus, los ancestros, las montañas.

Pero en otros pueblos diseminados en tonto al Salar de Atacama, las comunidades mantienen vivas algunas prácticas rituales. En Socaire, por ejemplo, una vez al año, se baila y canta al son de las palabras del Talatur.

El Talatur, también conocido coleo la danza de Saire (lluvia), es cantado en kunza y anualmente repelido con ocasión de la limpia de canales. Es uno de los rituales más importantes del ciclo calendárico agrícola, y creo que provee argumentos a favor de una interpretación fractal de la cosmología atacameña.

En su texto ${ }^{4}$, se pueden distinguir cuatro instancias cosmológicas diferentes: "Primero, una rogati-

4 EI texto se encuentra reproducido integralmente y traducido al español en Núñez, 1992:239-240. 
va "cósmica" frente a los cerros tutelares, dadores del agua (versos 1 al 7). Segundo, un llamado al "multiplico" de la tierra cultivada, para la reproducción del alimento cotidiano (versos 8 al 11). Tercero, una invocación a la reproducción humana y a la tierra como una sola unidad alegórica (verso 12), y, cuarto, un nivel más civil de Convivencia con el grupo festejante, vinculado con brindis y comidas una vez ya terminado el rito de la rogativa entre el mediador, su comunidad, y el espiritu de la montaña' (Núñez 1992:238).

\section{El estructuralismo revisitado}

A estas alturas del argumento, y habiendo interpretado ya algunos aspectos de lo que parece ser una cosmología coherente, se puede sacar a luz lo que algunos han denominado el "andamiaje" (Allen 1988:37) en virtud del cual la manera andina de ver el mundo se sostendría. Los conceptos "clave" mencionados a lo largo de este capítulo se articularían gracias a algunos principios organizadores que se pueden resumir con la ayuda de Isbell, y que son: a) dualidad, en virtud de la cual "los fenómenos se reflejan los unos a los otros" (Isbell 1978:11); b) complementariedad, particularmente la de géneros: "la complementariedad sexual es quizás el concepto usado más extensivamente para clasificar ,fenómenos cosmológicos V naturales" (ibíd.), y; e) "reciprocidad en el trato social, en relaciones tanto simétricas como asimétricas"(ibíd.).

Más que principios estructurales subyacentes, sin embargo, estas ideas representan las relaciones integrales a diversos motivos y temas. Parafraseando a Tilley (1994:17), estas relaciones son a la vez ontológicamente constitutivas y socialmente constituidas, no un marco estructural que se pueda desprender intelectualmente. Los Atacameños, la Pachamama Santa Madre Tierra, los Mallkus y el Ayllu se definen en las relaciones que los unen, a la vez de constituirlas.

El "paisaje" no es, entonces, meramente simbólico, $\mathrm{o}$ a ser interpretado como un signo. Es a la vez todo y parte de conjuntos enteros de relaciones que sostienen al orden natural. Por supuesto que, como ocurre en muchas sociedades agrícolas, el "paisaje" también es observado o sentido en los huesos, y existen muchas reglas interpretativas para los más diversos signos climáticos.

\section{El paisaje disputado: etnicidad, territorio y ley}

Los "paisajes" no existen realmente en la manera en que los he descrito hasta ahora (pero quizás serán o fueron). Son tipos ideales. Lo que se podría encontrar en el desierto de Atacama son muchos "paisajes" diferentes (quizás los haya tanto como hay gente), hechos con retazos y pedazos del discurso del desarrollo y de la cosmología atacameña, entre otras narrativas y modos de ver el mundo posibles. Los que he intentado mostrar son, sin embargo, los extremos quizás más influyentes de un continuo de posibilidades, sobre el cual se sostienen una miríada de lebenswelt sincréticos, entremezclados en la vida diaria común de un campesino atacameño. Muchos de los elementos que la mente euroamericana considera como indispensables componentes del "paisaje" juegan roles gravitantes y complejos en la vida atacameña, otros no. Los atacameños no viven expresamente una manera de ver el mundo que sea coherente y libre de contradicciones cosmológicas y vitales, y, sin embargo, las figuras y motivos que he indicado están presentes, informan de algún modo las actividades cotidianas. Ningún atacameño que yo haya conocido, por ejemplo, beberá de algo antes de haber vertido un poco en ofrenda a la Pachamama. Esto ocurre por igual en contextos sagrados y vernaculares.

Es también un hecho que muchos atacameños utilizan con cada vez mayor frecuencia términos como "desarrollo con identidad", "progreso", "patrimonio cultural", etc. Preocupaciones "modernas" en torno a la colegiatura de los niños, salud pública, complejos deportivos, electricidad y otros "servicios", corresponden a intereses que son, naturalmente, también perseguidos por los atacamehos.

Todos los elementos dados se combinan en cantidades diferentes, a cada uno de ellos atribuyéndoseles grados variados de importancia.

Pero esto no es todo, sin embargo, pues más allá del fácil y didáctico escenario de "lo moderno contra lo tradicional", primero de manera pausada y luego con una organización cada vez mayor, los atacameños han empezado a expresar reivindicaciones políticas. Los planes de desarrollo, producidos burocráticamente por el Estado, no son simplemente absorbidos por ellos. Con una capacidad para actuar que trataré de ilustrar, las diferentes comunidades algunas veces logran apropiarse del discurso planificador en su propio beneficio, mucho más allá de lo previsto por la retórica estatal.

\section{l.a Ley Indígena}

Tras algunos años de un forcejeo político llevado 
adelante tanto por indígenas como por no indígenas, el 5 de octubre de 1993, el parlamento chileno aprueba, por unanimidad, la denominada "Ley Indígena". Es el primer cuerpo legal chileno que reconoce la existencia de grupos étnicos "originarios" otros que el mapuche.

Esta ley define a los indígenas como "descendientes de las agrupaciones humanas que existen en el territorio nacional desde tiempos precolombinos, que conservan manifestaciones étnicas y culturales propias siendo para ellos la tierra el fundamento principal de su existencia y cultura" (Artículo 1). Atacameños, quechuas y collas están entre aquellas etnias reconocidas.

La ley, sin embargo, ha tenido efectos inesperados: Una comunidad quechua y otra de mayoría aimara, ambas asentadas en la región de Antofagasta, han optado por constituirse legalmente como comunidades indígenas atacameñas. Esta opción les permitiría evitar desventajas en la competencia por fondos estatales especiales, distribuidos regionalmente por un grupo de líderes atacameños. Comunidades como Toconce, Lasana o Chiu-Chiu, compuestas en su mayoría por personas de origen aimara o quechua, se declararon atacameñas. Ya a finales de 1995 se habían legalmente constituido 18 comunidades atacameñas (y una quechua). Sin advertir que estaba reordenando las configuraciones étnicas existentes, la ley había iniciado "un proceso de reetni-ficación desde el Estado"(Rivera 1994:189), un proceso que había sido intencionalmente iniciado para permitir a las estructuras estatales tratar con grupos humanos claramente identificables (v.gr. administrables y controlables).

Antes de la ley, la gran mayoría de los atacameños no tenía una autocomprensión identitaria esencialista o supremacista ni se atribuía un origen primordial. La generación de discursos intolerantes, creo yo, ha sido en gran parte, producto del encuentro entre la narrativa tradicional y el redoblado discurso del desarrollo. La ley, al ofrecer ventajas y privilegios a personas pertenecientes a la etnia, ha catalizado un proceso de politización dentro de las comunidades atacameñas que ha significado, en algunas ocasiones, que las autoridades tradicionales sean desplazadas. Los grupos étnicos, en competencia por fondos estatales, se han dividido en aún más facciones políticas.

Los no indígenas viviendo en o cerca de San Pedro de Atacama están siendo discriminados con mayor violencia que en el pasado, al representar, entre otros, a potenciales beneficiados de recursos estatales destinados a favorecer, en principio, exclusivamente a los atacameños.

Líderes indígenas que habían surgido de movimientos sociales de base fueron puestos a cargo de oficinas indígenas a lo largo de todo Chile. Poco a poco, los privilegios y estabilidad de la vida funcionaria han ganado cierto ascendiente entre los diversos elementos a considerar en el proceso de toma de decisiones que efectúan estos empleados públicos. Los intereses del Estado y los planes de desarrollo han ganado más apoyo del que solían tener. Pude observar en varias ocasiones como un empleado público indígena posponía los claros intereses de las comunidades a cuyo grupo étnico pertenecía, para apoyar mega proyectos estatales que representaban una amenaza para la supervivencia cultural de las mismas. De no brindar su apoyo, su posición funcionaria se vería amenazada.

El proceso de cooptación que realiza el Estado por medio de la legalización, demarcación y subsidio no es para nada novedoso, $\mathrm{y}$, tiene patrones reconocibles.

Más arriba utilicé las palabras de Hugh Brody para explicar un proceso similar en la Columbia Británica de Canadá. Del mismo modo que lo que ha ocurrido en Chile, el primer paso estratégico que allá se dio fue circunscribir legalmente a la población indígena, amarrándolas a reglas y obligaciones por las cuales pudieran responder.

Luego, los líderes más carismáticos fueron colocados en posiciones de poder bien pagadas. Para muchos de ellos, les ha sido difícil resistir las tentaciones que provoca el poder estatal.

Una vez amarradas las organizaciones indígenas, y sus líderes cooptados, el Estado selectivamente da recursos a algunas comunidades, las más dóciles. Dividir para reinar.

\section{Reclamaciones territoriales}

La ley Indígena también declara que la CONADI (Corporación Nacional de Desarrollo Indígena), "realizará en conjunto con el Ministerio de Bienes Nacionales, durante los tres años posteriores a la publicación de esta ley, un plan de saneamiento de titulos de dominio sobre las tierras aimaras $y$ atacameñas de la 1 y II regiones" (Artículo 3 Transitorio).

Este artículo de la ley obliga al Estado a identificar las tierras a ser saneadas en beneficio de las comunidades Atacameñas y Aimaras. Agrega la ley que, la CONADI "en los procesos de saneamiento y 
constitución de la propiedad de las comunidades señaladas..., deberd salvaguardar los siguientes tipos de dominio:

a) Tierras de propiedad de indígenas individualmente considerados, que por lo general comprenden la casa habitación y terrenos de cultivo y forraje:

b) Tierras de la propiedad de la Comunidad Indigena constituida en conformidad con esta ley y correspondiente, por lo general, a pampas $y$ laderas de cultivo rotativas.

c) Tierras patrimoniales de propiedad de varias Comunidades Indigenas tales como pastizales, bofedales, cerros, vegas y otras de uso del ganado auquénido" (Artículo 63).

El Estado chileno, a mediados de 1996, se propuso, entonces, hacer el catastro de la tierra que luego regularizaría o traspasaría. A algunos antropólogos les fue asignado el importante rol de determinar, en terreno, qué tierras eran indígenas. Mi rol era explicar las implicaciones legales que tal traspaso tendría. En un inicio, el interés que manifestaron algunos miembros de las comunidades visitadas, giró en torno al título ele dominio individual.

Al señalar las consecuencias que tendría el reconocimiento legal de las tierras comunitarias y tradicionales, esto es, la constitución cíe un territorio que sería de propiedad exclusiva de la comunidad, se fueron dando cuenta que esto significaría que ellos podrían decidir quién y cómo utilizaría los recursos existentes en dicho territorio, y esto, solo si aceptaban que los recursos fueran explotados. Adicionalmente, una prohibición legal de vender estas tierras aseguraba que ellas les pertenecerían por generaciones.

No sabían cual era la extensión o superficie de sus tierras ancestrales, ni tenían una noción cartográfica de las mismas. Y, sin embargo, conocían muy bien los linderos tradicionales de cada comunidad, y los recursos a los cuales cada comunidad tenía derecho, o compartían. Lo que más me sorprendió fue el cambio que muchos tuvieron, desde una resignación a la marginalidad, hacia el darse cuenta que tenían una oportunidad de asegurar el control comunitario sobre sus tierras y los recursos que éstas guarecían.

Allen señala "El ritual andino trabaja para tener, controlar y dirigir el flujo del Sami", término que ella define como un 'flujo de espiritu vital, inherente a toda la materia, similar, en principio (no asociado en la práctica) a nuestro concepto de energía" (Allen 1988:50).
Las huellas que pisan los atacameños, las montañas a las que invocan para obtener protección, el agua que les es dada en recompensa por su trabajo, los ancestros, la Pachamama, todos son parte del flujo continuo de vida, muerte y regeneración, un flujo que adopta tal o cual forma reconocible, una composición relacional interna que es sacada a luz por medio del ritual.

Poco a poco, siguiendo otros patrones relacionales y visuales, el mundo euroamericano ha tomado las aguas que los atacalneños ocuparon por milenios, expide toneladas de humo arsenicoso, ha vaciado a los oasis y poblados de vida, rituales y canciones atacameños, y además, los precios de los huertos y propiedades han subido, entre otras razones, por la presión ejercida por un turismo incontrolado.

En Chile los papeles son muy importantes, si no tienes a uno que lo demuestre, no eres dueño de nada. los Atacameños ahora tenían la oportunidad de obtener un título sobre todo aquello que pudieran demostrar como de su pertenencia.

Les pedí todos los documentos que pudieran tener, títulos antiguos constituidos por sus antepasados, concesiones sobre yaretales, regularizaciones de hace 50 años atrás que habían quedado inconclusas.

Pero el uso efectivo de la tierra debía también ser demostrado: un funcionario del Ministerio de Bienes Nacionales sugirió hacer las cosas sencillas y efectuar el traspaso de 1 hectárea de tierra por llama, más aquella tierra que estuviera actualmente en cultivo.

Definir la ocupación tradicional atacameña, sin embargo, era un asunto más complejo.

Paisaje, montañas, huellas troperas, quebradas, lagunas, pantanos, lugares desde los cuales se colecta las plantas medicinales o en los cuales las llamas suelen pastar, los sitios arqueológicos e históricos, los lugares sagrados, aquellos con nombres y significados indígenas: todo era parte de lo que consideraban propio. Este sentido de propiedad, que a primeras luces parece excesivo, por la extensión de tierra que pudiera resultar, está íntimamente relacionado con el modo de vida atacalneño y el denominado principio de complementariedad ecológica, en virtud del cual los recursos que se obtienen en un nicho altitudinal (y ecológico) dado se complementan con otros recursos obtenidos en pisos ecológicos diferentes. Además, al ser la densidad de la biomasa tan baja en el desierto, obtener alimentos $y$ realizar los trajines diarios implica recorrer grandes distancias.

Un equipo de antropólogos, junto a un abogado 
y a los miembros más antiguos de las comunidades lograron una primera cifra aproximada de tres millones de hectáreas a regularizar.

La gente del Ministerio de Bienes Nacionales se sorprendió y se asustó. Nunca imaginaron que las reclamaciones territoriales atacaneñas llegarían a tanto. Como habían proporcionado los fondos del proyecto, decidieron "recomendar" a los consultores a cargo del catastro que redujeran esta figura preliminar cambiando "los criterios para establecer el uso del suelo". Un funcionario del Ministerio me dijo que nunca entregarían todo lo identificado: el Ministerio tenía otros elementos a considera como parte de su misión. "-¿Cómo cuáles?", pregunté. "- Como el desarrollo", me contestó. La posibilidad de que la tierra traspasada no fuera "desarrollada" por los atacameños de manera adecuada, era anatema e iba contra las políticas gubernamentales.

El deseo de ser actores principales en el manejo de lo que ellos consideran sus territorios ancestrales ha llevado a que los atacameños no sólo reclamen el territorio que es esencial a su reproducción material, si no que el derecho a legalmente controlar el "escenario", en la misma manera en que lo hace el discurso del desarrollo.

Así los Atacameños (y sus abogados) tal vez tendrán que utilizar el concepto euroamericano de "paisaje" para contrarrestar la ávida mirada occidental. Deberán traducir a su Pachamama y los diálogos que con ella tienen en términos de paisaje, territorio y uso de suelo, a fin de evitar la explotación absurda.

El Estado, sin embargo, es quien, por ahora, controla el proceso de devolución, es juez y parte: los resultados del proceso son aún inciertos. Pero de algo se puede estar seguro, los Atacameños sostendrán su reclamo ante todas las instancias posibles.

\section{CONCLUSION}

El poder del Estado se explaya a nivel micro a través de técnicas de disciplinamientos cada vez más sutiles y no por eso menos efectivas. He tratado de mostrar cómo éstas están siendo resistidas, subvertidas y apropiadas para acrecentar el poder de la localidad y de la gente que desafía ser tratada como títeres en un escenario, y esto, sin importar lo promisorio del guión estatal. Los atacameños entienden que su situación de poder mejora, no por ser invitados a los esquemas "participativos" de programas elaborados en los términos del planificador, sino que al controlar los recursos asociados a la vida en el desierto. Muchos atacameños están, por primera vez, asumiendo una una "identidad étnica", lo que algunos consideran una estrategia de supervivencia o un "instinto de conservación étnico" (Pourrut 1995:110), donde lo étnico se encuentra asociado a cierto modo de vida en el desierto, a una manera única de relacionarse con el paisaje.

He presentado a propósito al "paisaje" atacameño enfrentado al del desarrollo en una oposición dialéctica. Como síntesis, delineé la situación actual respecto de las reclamaciones territoriales, la demanda por mayor control de recursos y respeto por el "modo de vida atacameño."

El sincretismo, sin embargo, no es sólo un asunto de dialéctica. Los complejos elementos que entreveran al tejido social atacameño con la sociedad "chilena" mayor no pueden resumirse en un modelo triádico. Tampoco serviría dar una cuenta completa de todos y cada uno de los elementos y motivos que componen al mundo Atacameño y a la versión chilena del discurso del desarrollo.

Sólo se pretendía mostrar cómo prácticas "paisajísticas" del desarrollo implican cambios en el modo de ser-en-el-mundo de la gente, modificando en consecuencia el modo que ésta tiene de relacionarse, parte esencial de cualquier definición cultural. Si se ha de respetar la diversidad cultural, se deberá respetar el modo que cada cultura tenga de relacionarse con su entorno natural y social, con su "paisaje".

El "paisaje" no sólo refleja la historia de los pueblos y sus relaciones: su ingrediencia activa se mezcla con la del cuerpo (individual y social) en maneras únicas y a través del tiempo. Es parte y todo de una relación que para algunos pueblos es muy significativa, e incluso, vital. En este entendimiento, las prácticas "paisajísticas" del desarrollo tienen el potencial de alterar, degradar o cortar severamente los delicados lazos creados, mantenidos y lentamente modificados a través de miles de años de supervivencia en el desierto.

En reemplazo, el discurso del desarrollo promete los beneficios de vivir en una sociedad moderna, urbanizada e industrial: un futuro mítico es inscrito en el "paisaje". Para los planificadores del desarrollo, sólo el futuro cuenta, un futuro al menos tan ilusorio para los atacameños como el concepto euroamericano de "pasado". Las promesas del desarrollo rara vez se cumplen, y sin embargo a la gente igual se le obliga a soportar los diseños "paisajísticos" oficiales. El mítico "paisaje" desarrollado retrocede al ritmo de promesas incumplidas, pero es incansablemente reformulado para refrescar las esperanzas.

Respecto de la facilidad con que el "paisaje" de 
los euroamericanos se ajusta a los imperativos del discurso del desarrollo; tal vez se deba al hecho de que después de tanto tiempo de interacción intensiva, ambos comparten los supuestos visualistas de la civilización "especulativa" de la cual provienen, en la cual el "sujeto" lo está realmente.

\section{Nuevas dicotomías}

La violencia implícita en estas manipulaciones se ha manifestado en la construcción sincrética de una nueva y poderosa dicotomía en San Pedro de Atacama: aquella entre "sampedrinos" y "afuerinos". Esta construcción dual atraviesa ahora la mayor parte del horizonte social atacameño en una manera similar a la que es descrita por Isbell para la comunidad chuschi, es decir, polarizada entre "los e Iranjerv.c dominadores y los miembros indígenas de la comunidad" (Isbell 1978:11). Puede ser visto como una estrategia para contrarrestar el poder de la dominación foránea. Pero el discurso de la intolerancia también puede ser entendido como una herramienta utilizada por aquellos que, dentro de la comunidad atacameña, quieren tener poder sobre los demás comuneros. El ser indígenas ha significado, para algunas familias atacameñas, el privilegio ele tener puestos de trabajo bien remunerados en reparticiones estatales, además de estar a cargo de gran parte de los proyectos de desarrollo con financiamiento público. Se ha formado una elite a la cual le conviene atizar este discurso para proteger su posición.

Tal vez esto se explica como una versión mas del "cuento popular" en que los atacameños transforman lo que han vivido y viven (leen, ven y oyen), la actividad narrativa permanente que realiza el desarrollo promovido desde el Estado chileno. La polarización existente entre "afuerinos" y "sampedrinos" puede ser el resultado de un bricolaje cosmológico, un intento por entender, reflejar, substanciar y conjurar a nivel micro, la violencia del discurso del desarrollo.

\section{BIBLIOGRAFIA}

APPADURAI. A. Mo(Iernrityat Large: $e$ : Cultural Dimensions of 1996 Globalization, Minneapolis: University of Minnesota Press.

BASSO, K.H. «Wisdom sits in places» en Feld, S. y Basso, K.H. 1996 (eds.) Senses of Place. Santa Fe: School of American Research Press.

BASTIEN, J. Mountain of the Condor, St. Paul, West Publi1978 skiing Co.

BENDER. B. (ed.) Landscape: Politics and Perspectives, Oxford. 1993 Berg.

BOYER, P. The Naturalness of Religious Ideas: A Cognitive 1994 Theory of Religion, London: U nivesity of California Press.

B RO DY, H. Maps and Dreams, London: Jill Norman \& Hobhouse. 1981

CASEY, E. «How to gel from place to space» en Feld. S. y Basso. 1996 K.II. (eds.) Senses of Place. Santa Fe: School of American Research Press.

CASTRO, V. y VAREL.A. V. (eds.) Ceremonias de Tierra y 1994 Agua: Ritos Milenarios Andinos. Santiago: Kuppenheinr y Cía.

CROLL, E. y PARKIN. D. (eds.) Bush Base: Forest Farm, 1992 Culture, Environment and Development, London: Routledge \& Kegan Paul.

CRUSH, J. (ed.) Power of Development, London: Routledge. 1995
DOUGlas, M. Purity and Danger. London: Routledge \& 1966 Kegan Paul.

ERD - Estrategia Regional de Desarrollo, II Región Intendencia

1994 II Región. Antofagasta: NORprint.

ESSAN Plan de Desarrollo para los Servicios de Agua Pota1992 ble y Alcantarillado de ESSAN S.A. Definición del I'royectode Inversión, Tomo 11. Santiago. Marzo.

ESCOBAR. A. .Reflections ou "development"», Futures 24,55: 1992 411-436.

ESCOBAR, A. «Imagining a Post Development Era» en Crush. 1995 J. (ed.) Power of Development. London: Routledge.

ESTEVA. G. «Development» en Sanchs, W. (ed.) The Develop1992 ment Dictionary: A Guide to Knowledge as Power, London \& New Jersey: Zed Books.

FELD S. y BASSO K. H. (eds.) Senses of Place, Santa Fe: 1996 School of American Research Press.

FOUCAUlT, M. Discipline and Punish: The Birth of the Pri1984 son. I-tarmondsworth: Penguin.

GEERTZ, C. The Interpretation of Cultures, New York: Basic 1973 Books

GODELIER, M. y Strathern. M. (eds.) Big Men .rid Great Men, 1991 Cambridge: Cambridge University Press. 
GREBE, M.E. «Etnoecología nativa en las culturas andinas» Re1990 vista de Antropología, Santiago: Universidad de Chile.

HIRSCHY O'HANLON (eds.)TheAnthropology of Landscape: 1995 Perspectives of Place and Space, Oxford: Clarendon Press.

INGOLD, T. «Culture and the perception of the environment», en 1992 Croll, E. y Parkin, D. (eds.) Bush Base: Forest Farm, Culture, Enviroment and Development, London: Routledge.

INGOLD, T. «The temporality of the landscape», en World Ar1993 chaeology 25,2:152-74.

INGOLD, T. «Building, dwelling, living: how animals and peo1995 ple make themselves at home in the world» en Strathern, M. (ed.) Shifting Contexts: Transformations in Anthropoogical Knowledge, London: Routledge.

INYGE «Análisis y Planificación de los Recursos de Agua en la 1991 Segunda Región de Antofagasta». Informe Final. Santiago.

ISBELL, B. J. To Defend Ourselves: Ecology and Ritual in an 1978 Andean Village. Austin: University of Texas Press.

JOHNTON, H. «The British Central Africa Protectorate» 1895 Georaphical Journal 5,3:193-217.

KUCHLER, S. «Landscape as memory: the mapping of process 1993 and its representation in a melanesian society», en Bender, B. (ed.) Landscape: politics and perspectives, Oxford, Berg.

LEHNERT, R. Diccionario Toponimia Kunza, Antofagasta: $1994 \quad$ NORprint.

LEY INDIGENA, Ley No 19.253, Diario Oficial de Chile, 5/10/ 1993 93, Santiago.

Merleau-POnTy, M. [1945] Phénomenologie de la Percep1981 tion, Gallimard.

MITCHELL, T. «America's Egypt» en Crush, J. (ed.) Power of 1995 Development, London: Routledge.

MORPHY, E. «Colonialism, history and the construction of pla1993 ce: the politics of landscape in northern Australia» in Bender. B. (ed.) Landscape: politics and perspectives, Oxford, Berg.

MURRA. J., WACHTEL, N. y REVEL. J. (eds.) Anthropological 1986 History of Andean Polities, Cambridge: Cambridge University Press.x

NÚÑEZ, L. Cultura y Conflicto en los Oasis de San Pedro de 1992 Atacama, Santiago: Editorial Universitaria.

PINNEY, C. «Future travel: anthropology and cultural distance in 1992 an age fo virtual reality; or, a past seen from a possible future». Visual Anthropology Review 10 (1): 10-43.
PLATT, T. «Mirrors and maize: the concept of yanant in among 1986 the Machaof Bolivia» in Murra. J., Wachtel, N. y Revel, J. (eds.) Anthropological History of Andean Polities, Cambridge: Cambridge University Press.

POURRUT, P. «('011clusion» Programa DURR en EI Desierto, 1994 el Hombre y el Agua, ORSTOM, Universidad Católica del Norte: NORprint.

REDFORD, K.H. y STEAMEN, A.M. «On common ground? 1993 Response to Alcorn.' Conservation Biology 7 (2), 427-428.

RIVERA, F. «Identidad en el laberinto: la búsqueda del sentido 1994 étnico en San Pedro de Atacama», Estudios Atacameños $\mathbf{N}^{\mathbf{1}}$ 11, 185-194.

RIVERA, F. «Riego, sistema social e historia en San Pedro de Ata1994 cama», Programa DURR en El Desierto, el Hombre y el Agua, ORSTOM, Universidad Católica del Norte: NORprint.

SACHS, W. (ed.) The Development Dicctionary: A Guide 1992 to Knowledge as Power, London $8 \mathrm{z} \mathrm{New}$ Jersey: Zed Books.

SCHAMA, S. Landscape and Memory, London: Fontana Press. 1996

STRATHERN, M. «Environments within: an ethnographic 1997 commentary on scale» The Linacre Lecture 1996-1997, Culture and Environment, Linacre College. Oxford.

STRATHERN, M. «One legged gender» in Lucien Taylor (ed.) $1994 \quad$ Visualizing Theory. Selected Essays From V.A.R. 1990-1994, London: Routledge.

THOMAS, J. «The politics of vision and the archaeologies of 1993 landscape» en Bender, B. (ed.) Landscape: Politics and Perspectives, Oxford, Berg.

TILleY, C. a Phenomenology of Landscape: Places, Paths 1994 and Monuments, Oxford: Berg.

TURNER, T. en Marx, L. et al. (eds.) Earth, Air, Wind, Fire, 1996 Cambridge: MIT Press.

URTON, G. At the Crossroads of the Earth and the Sky: 1981 An Andean Cosmology, Austin: University of Texas Press.

WAGNER, R. «The Fractal Person» en Godelier, M. y Strathern, 1991 M. (eds.) Big Men and Great Men, Cambrigde: Cambridge University Press.

WEINER, J. «Qn televisualist anthropology: representation. 1997 aesthetics, politics» en Current Anthropology. 